\title{
PENERAPAN SANKSI HUKUM TERHADAP ANAK SEBAGAI KURIR NARKOBA BERDASARKAN UNDANG-UNDANG NOMOR 35 TAHUN 2014 TENTANG PERLINDUNGAN ANAK
}

\author{
OLEH : \\ PUTRI SARI NILAM CAYO,SH.,MH \\ (Dosen Tetap Sekolah Tinggi Ilmu Hukum Sumpah Pemuda Palembang)
}

\begin{abstract}
ABSTRAK
Anak merupakan generasi penerus bangsa. Untuk itu diperlukan Perundangundangan yang melindungi anak dari berbagai tindak pidana, yaitu Undang-Undang No.35 Tahun 2014 Perubahan atas Undang-Undang No.23 Tahun 2002 Tentang Perlindungan Anak. Tujuan dari undang-undang ini sendiri yaitu untuk melindungi hak-hak anak dari segala macam tindak pidana salah satunya tindak pidana narkotika.

Terhadap anak-anak yang menjadi kurir atau perantara narkotika, harus didasarkan pada mekanisme yang diatur dalam UU No.35 Tahun 2014 Perlindungan anak dan UU No. 11 Tahun 2012 Tentang Sistem Peradilan Anak. Penegakan hukum bagi pelaku yang masih berusia di bawah, terdapat ketentuan khusus yang dinamakan dengan diversi, yakni pengalihan penyelesaian perkara anak dari proses peradilan pidana ke proses di luar peradilan pidana.
\end{abstract}

\section{Kata Kunci : Sanksi Hukum, Kurir Narkoba, Anak}

\section{ABSTRACT}

Children are the next generation of the nation. For this reason, legislation is needed to protect children from various criminal acts, namely Law No. 35 of 2014 Amendment to Law No.23 of 2002 concerning Child Protection. The purpose of this law itself is to protect the rights of children from all kinds of criminal acts, one of which is narcotics crime.

Children who are couriers or narcotics brokers must be based on the mechanism stipulated in Law No. 35 of 2014 on Child Protection and Law No. 11 of 2012 concerning the Juvenile Justice System. Law enforcement for perpetrators who are under the age, there is a special provision called diversion, namely the transfer of the settlement of the case of children from the criminal justice process to the process outside of criminal justice.

\section{Keywords: Legal Sanctions, Drug Couriers, Children}

\section{A. LATAR BELAKANG}

Anak adalah karunia yang terbesar bagi keluarga, agama, bangsa dan negara. Dalam kehidupan berbangsa dan bernegara anak adalah penerus cita-cita bagi kemajuan suatu bangsa. Anak adalah tunas, potensi, dan generasi penerus cita-cita bangsa. Mereka memiliki peran strategis dalam menjamin eksistensi bangsa dan negara pada masa yang 
akan datang. ${ }^{44}$ Pengertian anak menurut Pasal 1 ayat 1 UU Nomor 35 Tahun 2014 adalah: "Anak adalah seseorang yang belum berusia 18 (delapan belas tahun) termasuk anak yang masih dalam kandungan”. Sedangkan menurut Pasal 1 KHA / Keppres No.36 Tahun 1990 "anak adalah setiap orang yang berusia di bawah 18 tahun kecuali berdasarkan UU yang berlaku bagi yang ditentukan bahwa usia dewasa dicapai lebih awal.

Upaya perlindungan anak perlu dilaksanakan sedini mungkin, yakni sejak janin dalam kandungan, sampai anak berumur 18 tahun (delapan belas) tahun. Anak harus dilindungi dari segala bentuk ketelantaran, kekerasan, penganiayaan. Ia tidak boleh dijadikan subyek perdagangan anak, tidak boleh bekerja sebelum usia tertentu, ia tidak boleh dilibatkan dalam pekerjaan yang dapat merugikan kesehatan atau pendidikannya, serta dapat mempengaruhi perkembangan tubuh, jiwa dan akhlaknya.

Perlindungan terhadap anak sangat penting, mengingat anak merupakan generasi penerus bangsa. Untuk itu diperlukan Perundang-undangan yang melindungi anak dari berbagai tindak pidana, yaitu Undang-Undang No.35 Tahun 2014 Perubahan atas UndangUndang No.23 Tahun 2002 Tentang Perlindungan Anak. Tujuan dari undang-undang ini sendiri yaitu untuk melindungi hak-hak anak dari segala macam tindak pidana salah satunya tindak pidana narkotika.

Adapun pengertian Narkotika berdasarkan Pasal 1 butir 1 UU. No. 22 Tahun 1997 adalah :

Zat atau obat yang berasal dari tanaman atau bukan tanaman baik sintetis maupun semi sintetis yang dapat menyebabkan penurunan atau perubahan kesadaran, hilangnya rasa, mengurangi sampai menghilangkan rasa nyeri, dan dapat menimbulkan ketergantungan, yang dibedakanke dalam golongan-golongan sebagaimana terlampir dalam Undang-undang ini atau yang kemudian ditetapkan dengan Keputusan Menteri Kesehatan.

Sedangkan menurut Pasal (1) angka 1 Undang-undang No. 35 Tahun 2009 tentang Narkotika, menyebutkan bahwa :

“ Narkotika adalah zat atau obat yang berasal dari tanaman atau bukan tanaman, baik sintetis maupun semisintetis, yangdapat menyebabkan penurunan atau perubahan kesadaran, hilangnya rasa,mengurangi sampai menghilangkan rasa nyeri, dan dapat menimbulkanketergantungan, yang dibedakan ke dalam golongangolongan sebagaimana terlampir dalam Undang-undang ini”

Penyalahgunaan narkotika dan psikotropika merupakan suatu problema yang sangat kompleks, karena itu butuh kesadaran dari semua pihak baik dari pemerintah, masyarakat 
maupun pelaku itu sendiri untuk segera sadar akan bahaya tersembunyi, tidak kelihatan (tetapi mempunyai potensi untuk muncul) dari penyalahgunaan narkotika dan psikotropika.

Pada saat ini narkotika sudah merambah kepada setiap kalangan. Untuk mengelabuhi pihak berwajib, tidak jarang para pengedar narkotika memanfaatkan anak di bawah umur untuk dijadikan kurir obat-obatan terlarang tersebut.

Kurangnya pengetahuan terhadap narkotika, dan ketidakmampuan untuk menolak serta melawan membuat anak di bawah umur menjadi sasaran bandar narkotika untuk mengedarkan narkotika secara luas dan terselubung. Selain itu penyebaran narkotika dan psikotropika menjadi makin mudah karena anak Sekolah Dasar (SD) juga sudah mulai mencoba-coba menghisap rokok. Tidak jarang pengedar narkotika dan psikotropika menyisipkan zat-zat adiktif (zat yang menyebabkan efek kecanduan) kepada lintingan tembakaunya. Pada awalnya mereka mengkonsumsi narkotika dan psikotropika biasanya diawali dengan perkenalannya dengan rokok. Dari kebiasaan inilah, pergaulan mulai meningkat, apalagi ketika anak tersebut bergabung ke dalam lingkungan orangorang yang sudah menjadi pecandu narkotika dan psikotropika. Awalnya mencoba, lalu kemudian ketergantungan bahkan ikut melakukan penjualan.Persoalan ini tentu menjadi masalah yang sangat serius, karena dapat menjerumuskan anak dibawah umur dalam bisnis gelap narkotika.

Pemidanaan terhadap anak tentunya tidak mungkin di persamakan dengan orang dewasa ,kemampuan anak yang masih terbatas dan tidak sesempurna orang dewasa Sehingga dari segi psikis dan niat inilah yang harus menjadi pertimbangan para aparatur penegak hukum lewat upaya perlindungan hukum berdasarkan UndangUndang Nomor. 35 Tahun 2014 Tentang Perlindungan Anak harus diperhatikan oleh aparat penegak hukum dalam menerapkan pemidanaan bagi anak pelaku tindak pidana narkotika, dikeluarkannya Undang-Undang Nomor 11 Tahun 2012 tentang Sistem Peradilan Pidana Anak sebagaimana pengganti dari Undang-Undang Nomor 3 Tahun 1997 tentang Pengadilan Anak akan memberikan penerapan pemidanaan yang lebih bersifat membina dan melindungi terhadap anak pelaku tindak pidana. ${ }^{45}$

Oleh karena itu, hal perlu mendapatkan perhatian yang serius. Penegak hukum dalam memproses dan memutuskan harus yakin benar bahwa keputusan yang diambil akan menjadi satu dasar yang kuat untuk mengembalikan dan mengatur anak menuju

45 Siti Zaenab, Perlindungan Hukum Terhadap Anak Sebagai Kurir Narkotika, Univ. Narotama, Surabaya: 2014, hlm., 3 . 
masa depan yang baik untuk mengembangkan dirinya sebagai warga masyarakat yang bertanggung jawab bagi kehidupan bangsa.

\section{B. PERMASALAHAN}

Adapun permasalah yang penulis ambil dalam tulisan ini adalah Bagaimana Penerapan Sanksi Hukum Terhadap Anak Sebagai Kurir Narkoba Berdasarkan UndangUndang Nomor 35 Tahun 2014 Tentang Perlindungan Anak?

\section{PEMBAHASAN}

Masalah peredaran narkotika saat ini sangat mengkhawatirkan,karena tidak hanya terjadi di kota-kota besar saja juga merambah ke pelosok Indonesia. Saat ini mafia narkoba punya modus baru untuk mengedarkan obat terlarang. Para bandar mulai kerap menggunakan pelajar dan anak-anak di bawah umur sebagai kurir maupun pengedar narkoba hal ini salah satu sebab supaya tidak mencurigakan. Permintaan anak untuk menjadi kurir diminta oleh senior mereka, teman-teman sepergaulan atau bahkan oleh orangtua untuk menjadi kurir atau pengedar.

Penerapan sanksi hukum terhadap anak sering menimbulkan perdebatan, karena dalam hal ini mempunyai konsekuensi yang sangat luas baik menyangkut perilaku maupun stigma dalam masyarakat dan juga dalam diri anak tersebu. Sanksi adalah alat pemaksa, dimana sanksi memaksa menegakkan hukum atau memaksa mengindahkan norma-norma hukum. Sanksi sebagai alat penegak hukum bisa juga terdiri atas kebatalan perbuatan yang merupakan pelanggaran hukum. Baik batal demi hukum maupun batal setelah ini dinyatakan oleh hakim ${ }^{46}$ Sedangkan pengertian hukum adalah norma yang mengarahkan masyarakat untuk mencapai cita-cita serta keadaan tertentu dengan tidak mengabaikan dunia kenyataan. Oleh karena itu, hukum terutama dibuat dengan penuh kesadaran oleh negara dan digunakan untuk mencapai suatu tujuan tertentu. ${ }^{47}$

Sanksi hukum terhadap anak tentunya tidak mungkin di persamakan dengan orang dewasa yang dimana sifat psikis dan niat daripada anak berbeda dengan orang dewasa, dimana tingkat kecakapan serta pemahaman akan hal-hal mengenai hukum tentulah belum di pahami secara mendalam. Sehingga dari segi psikis dan niat inilah yang harus menjadi pertimbangan

46 R. Subekti dan Tjitrosoedibyo, Kamus Hukum, Pradnya Paramita,Jakarta,2005,hlm.98

47 Bambang Sunggono, Hukum dan Kebijaksanaan Publik, Sinar Grafika, Jakarta, 2002,hlm.76. 
Terhadap anak-anak yang menjadi kurir atau perantara narkotika, harus didasarkan pada mekanisme yang diatur dalam UU No.35 Tahun 2014 Perlindungan anak dan UU No. 11 Tahun 2012 Tentang Sistem Peradilan Anak. Penegakan hukum bagi pelaku yang masih berusia di bawah, terdapat ketentuan khusus yang dinamakan dengan diversi, yakni pengalihan penyelesaian perkara anak dari proses peradilan pidana ke proses di luar peradilan pidana.

Sanksi hukum berupa pemidanaan yang lazim diterapkan berdasarkan KUHP, bukan mendidik anak menjadi lebih baik, melainkan memperparah kondisi dan dapat meningkatkan tingkat kejahatan anak.. Anak yang menjadi kurir narkotika, UU No. 35 tahun 2009 tentang narkotika tidak secara khusus mengatur mengenai ketentuan sanksi pidana bagi anak, namun pada dasarnya seorang anak yang melakukan tindak pidana narkotika sebagai pelaku peredaran gelap narkotika yaitu seorang anak yang menjadi kurir untuk menjalankan suatu proses peredaran gelap narkotika tetap dijerat dengan pasal-pasal sebagaimana yang ditentukan dalam ketentuan pidana yang diatur dalam undang-undang narkotika tetapi tidak mengesampingkan ketentuan khusus yang diatur UU No. 11 tahun 2012 tentang sistem peradilan pidana anak.

Berdasarkan Undang-Undang Nomor 35 Tahun 2014 tentang Perubahan Atas Undang-Undang Nomor 23 Tahun 2002 tentang Perlindungan Anak, Anak yang menjadi kurir narkotika pemeriksaan perkaranya wajib diupayakan diversi. Pengertian diversi Pasal 1 angka 7 UU 11 Tahun 2012 tentang sistem peradilan pidana anak yaitu pengalihan penyelesaian perkara Anak dari proses peradilan pidana ke proses di luar peradilan pidana. Namun diversi hanya dapat dilakukan dengan syarat ,yakni dalam hal tindak pidana yang dilakukan diancam dengan pidana penjara di bawah 7 (tujuh) tahun dan perbuatan yang dilakukan si anak bukan merupakan pengulangan tindak pidana.

Diversi merupakan pengalihan penyelesaian perkaraanak dari proses peradilan pidana ke proses diluar peradilan pidana. Komitmen untuk menerapkan restoratifjustice, khususnya dalam hal pelaku adalah anak-anak, harus didasarkan pada penghargaan terhadap anak sebagai titipan yang mempunyai kehormatan. Apalagi Indonesia adalah Negara pihak dalam Konvensi Hak-Hak Anak (Convention on the Rights of the Child). Sebagai negara pihak, Indonesia mempunyai kewajiban untuk memberikan pelindungan khusus terhadap anak yang berhadapan dengan hukum. ${ }^{48}$

48 Marlina, Peradilan Pidana Anak Di Indonesia pengembangan konsep diversi dan keadilan restoratif, Refika Aditama, Bandung, 2009, hlm. 198 
Menurut Undang-Undang No. 11 Tahun 2012 tentang Sistem Peradilan Pidana Anak,upaya diversi dilakukan untuk menghindari dan menjauhkan anak dari proses peradilan sehingga dapat menghindari stigmatisasi terhadap anak yang berhadapan dengan hukum dan diharapkan anak dapat kembali ke dalam lingkungan sosial secara wajar. Proses diversi dilakukan dengan melalui musyawarah yang melibatkan anak dan orang tua/walinya, pembimbing kemasyarakatan, dan pekerja sosial profesional, yang dilakukan dengan pendekatan keadilan restoratif.

Pengaturan anak-anak yang diproses secara hukum melalui peradilan pidana diatur dalam Pasal 3 Undang-Undang No. 11 Tahun 2012 tentang Sistem Peradilan Pidana Anak yang berbunyi :

Setiap anak dalam proses peradilan pidana berhak di antaranya:

a. Diperlaku secara manusiawi dengan memperhatikan kebutuhan sesuai dengan umurnya;

b. Dipisahkan dari orang dewasa;

c. memperoeh bantuan hukum dan bantuan lain secara efektif

d. Melakukan kegiatan rekreasional;

e. Bebas dari penyiksaan, penghu kum an atau perlakuan lain yang kejam, tidak manusiawi, serta merendahkan derajat dan martabat nya;

f. Tidak dijatuhi pidana mati atau pidana seumur hidup; dan

g. Tidak ditangkap, ditahan, atau dipenjara, kecuali sebagai upa ya terakhir dan dalam waktu yang paling singkat.

Sedangkan terhadap pertanggungjawaban pidana orang dengan menggunakan anak-anak sebagai kurirnya narkoba dapat dijerat dengan Pasal 133 ayat (1) UU No. 35 Tahun 2009 tentang Narkotika yang berbunyi :

Setiap orang yang menyuruh, memberi atau menjanjikan sesuatu, memberikan kesempatan, menganjurkan, memberikan kemudahan, memaksa dengan ancaman, memaksa dengan kekerasan, melakukan tipu muslihat, atau membujuk anak yang belum cukup umur untuk melakukan tindak pidana sebagaimana dimaksud dalam Pasal 111, Pasal 112, Pasal 113, Pasal 114, Pasal 115, Pasal 116, Pasal 117, Pasal 118, Pasal 119, Pasal 120, Pasal 121, Pasal 122, Pasal 123, Pasal 124, Pasal 125, Pasal 126, dan Pasal 129 dipidana dengan pidana mati atau pidana penjara seumur hidup, atau pidana penjara paling singkat 5 (lima) tahun dan paling lama 20 (dua puluh) tahun dan pidana denda paling sedikit Rp2.000.000.000,00 (dua miliar rupiah) dan paling banyak Rp20.000.000.000,00 (dua puluh miliar rupiah)

Sedangkan bagi kurir atau orang yang menjadi perantara rantai perdagangan narkotika, hukuman yang dapat dijerat tergantung pada jenis narkotika yang dibawanya. 
Adapun pengaturan pidana diatur dalam pasal 113, 114, 118, 119, 121, 144 UndangUndang Nomor 35 Tahun 2009 tentang Narkotika yaitu sebagai berikut:

Pasal 113 berbunyi :

(1) Setiap orang yang tanpa hak atau melawan hukum memproduksi,mengimpor, mengeksor atau menyalurkan Narkotika Golongan I, dipidana dengan pidana penjara paling singkat 5 (lima) tahun dan paling lama 15 (lima belas) tahun dan pidana denda paling sedikit Rp. 1.000.000.000,00 (satu miliar rupiah) dan paling banyak Rp. 10.000.000.000,00 (sepuluh miliar rupiah).

(2) (dalam hal perbuatan memproduksi, mengimpor, mengekspor, atau menyalurkan Narkotika Golongan I sebagaimana dimaksud pada ayat (1) dalam bentuk tanaman beratnya melebihi 1 (satu) kilogram atau melebihi 5 (lima) batang pohon atau dalam bentuk bukan tanaman beratnya melebihi 5 (lima) gram, pelaku dipidana dengan pidana mati, pidana penjara seumur hidup, atau pidanapaling singkat 5 (lima) tahun dan paling lama 20 (dua puluh) tahun dan pidana denda maksimum sebagaimana dimaksud pada ayat (1) ditambah 1/3 (sepertiga).

\section{Pasal 114 berbunyi :}

(1) setiap orang yang tanpa hak atau melawan hukum menawarkan untuk di jual, menjual, membeli, menerima, menjadi perantara dalam jual beli, menukar,atau menyerahkan Narkotika Golongan I, dipidana dengan pidana penjara seumur hidup, atau pidana penjara paling singkat 5 (lima) tahun dan paling lama 20 (dua puluh) tahun dan pidana denda paling sedikit Rp. 1.000.000.000,00 (satu miliar rupiah) dan paling banyak Rp. 10.000.000.000,00 (sepuluh miliar rupiah).

(2) dalam hal perbuatan menawarkan untuk di jual, menjual, membeli,menjadi perantara dalam jual beli, menukar, menyerahkan, atau menerima Narkotika Golongan I sebagaimana dimaksud pada ayat (1) yang dalam bentuk tanaman beratnya melebihi 5 (lima) batang pohon atau dalam bentuk bukan tanaman beratnya 5 (lima) gram, pelaku dipidana dengan pidana mati, pidana penjara seumur hidup, atau pidana penjara paling singkat 6 (enam) tahun dan paling lama 20 (dua puluh) tahun dan pidana denda maksimum sebagaimana dimaksud pada ayat (1) ditambah 1/3 (sepertiga).

Pasal 118 berbunyi :

(1) setiap orang yang tanpa hak atau melawan hukum memproduksi, memproduksi, mengimpor, mengekspor, atau menyalurkan Narkotika Golongan II, dipidana dengan 
pidana penjara paling singkat 4 (empat) tahun dan paling lama 12 (dua belas) tahun dan dipidana denda paling sedikit Rp. 800.000.000,00 (delapan ratus juta rupiah) dan paling banyak Rp. 8.000.000.000,00 (delapan miliar rupiah).

(2) dalam hal perbuatan memproduksi, mengimpor, mengekspor atau menyalurkan Narkotika Golongan II sebagaimana dimaksud pada ayat (1) beratnya melebihi 5 (lima) gram, pelaku dipidana dengan pidana mati, pidana penjara seumur hidup, atau pidana penjara paling singkat 5 (lima) tahun dan paling lama 20 (dua puluh) tahun dan pidana denda maksimum sebagaimana dimaksud pada ayat (1) ditambah 1/3 (sepertiga).

Pasal 119 berbunyi :

(1) setiap orang yang tanpa hak melawan hukum menawarkan untuk di jual, menjual, membeli, menerima, menjadi perantara dalam jual beli, menukar, atau menyerahkan Narkotika Golongan II, dipidana singkat 4 (empat) tahun dan paling lama 12 (dua belas) tahun dan dipidana denda paling sedikit Rp. 800.000.000,00 (delapan ratus juta rupiah) dan paling banyak Rp. 8.000.000.000,00 (delapan miliar rupiah).

(2) dalam hal perbuatan menawarkan untuk di jual, menjual, membeli,menjadi perantara dalam jual beli, menukar, menyerahkan, atau menerima Narkotika Golongan I sebagaimana dimaksud pada ayat (1) yang dalam bentuk tanaman beratnya melebihi 5 (lima) batang pohon atau dalam bentuk bukan tanaman beratnya 5 (lima) gram, pelaku dipidana dengan pidana mati, pidana penjara seumur hidup, atau pidana penjara paling singkat 5 (lima) tahun dan paling lama 20 (dua puluh) tahun dan pidana denda maksimum sebagaimana dimaksud pada ayat (1) ditambah 1/3 (sepertiga).

Pasal 121 berbunyi :

(1) setiap orang yang tanpa hak melawan hukum menggunakan Narkotika Golongan II terhadap orang lain atau memberikan Narkotika Golongan II untuk digunakan orang lain dipidana dengan pidana penjara paling singkat 4 (empat) tahun dan paling lama 12 (dua belas) tahun dan pidana denda paling sedikit Rp. 800.000.000,00 (delapan ratus juta rupiah) dan paling banyak Rp. 8.000.000.000,00 (delapan miliar rupiah).

(2) dalam hal penggunaan Narkotika terhadap orang lain atau pemberian Narkotika Golongan II untuk di gunakan orang lain sebagaimana dimaksud pada ayat (1) mengakibatkan orang lain mati atau cacat permanen, pelaku di pidana dengan pidana mati, pidana penjara seumur hidup, atau pidana penjara paling singkat 5 (lima) tahun 
dan paling lama 20 (dua puluh) tahun dan pidana denda maksimum pada ayat (1) ditambah $1 / 3$ (sepertiga).

Pasal 144 berbunyi :

(1) setiap orang yang jangka waktu 3 (tiga) tahun melakukan pengulangan tindak pidana sebagaimana di maksud dalam pasal 111, pasal 112, pasal 113, pasal 114, pasal 115, pasal 116, pasal 117, pasal 118, pasal 119, pasal 120, pasal 121, pasal 122, pasal 123, pasal 124, pasal 125, pasal 126, pasal 127 ayat (1), pasal 128 ayat (1), dan pasal 129, pidana maksimum ditambah dengan $1 / 3$ (sepertiga)

(2) ancaman dengan tambahan $1 / 3$ (sepertiga) sebagaimana dimaksud pada pasal ayat (1) tidal berlaku bagi pelaku tindak pidana yang di jatuhi dengan pidana mati, pidana penjara seumur hidup, atau pidana penjara 20 (dua puluh) tahun

\section{PENUTUP}

\section{Kesimpulan}

Terhadap anak-anak yang menjadi kurir atau perantara narkotika, harus didasarkan pada mekanisme yang diatur dalam UU No.35 Tahun 2014 Perlindungan anak dan UU No. 11 Tahun 2012 Tentang Sistem Peradilan Anak. Penegakan hukum bagi pelaku yang masih berusia di bawah, terdapat ketentuan khusus yang dinamakan dengan diversi, yakni pengalihan penyelesaian perkara anak dari proses peradilan pidana ke proses di luar peradilan pidana.

Berdasarkan Undang-Undang Nomor 35 Tahun 2014 tentang Perubahan Atas Undang-Undang Nomor 23 Tahun 2002 tentang Perlindungan Anak, Anak yang menjadi kurir narkotika pemeriksaan perkarany wajib diupayakan diversi. Pengertian diversi Pasal 1 angka 7 UU 11 Tahun 2012 tentang sistem peradilan pidana anak yaitu pengalihan penyelesaian perkara Anak dari proses peradilan pidana ke proses di luar peradilan pidana. . Namun diversi hanya dapat dilakukan dengan syarat ,yakni dalam hal tindak pidana yang dilakukan diancam dengan pidana penjara di bawah 7 (tujuh) tahun dan perbuatan yang dilakukan si anak bukan merupakan pengulangan tindak pidana

\section{Saran-saran}

a. Anak adalah anugrah penerus bangsa. Mulai dari anak dan pemuda bangsa ini bangkitdan melawan. Oleh karena itu segala perlindungan terhadap hak anak harus 
dibuat secaracermat sesuai realita yang terjadi di lapangan begitu juga pemerintah dapat melibatkan peran serta masyarakat.

b. Perlunya partisipasi masyarakat secara aktif dalam memberantas kejahatan narkotika dan psikotropika, Penguatan elemen masyarakat dari tataran paling bawah yaitu pada lingkungan RT/RW dan Kelurahan menjadi basis utama dalam melihat situasi dan kondisi lingkungan diwilayahnya masing-masing

\section{DAFTAR PUSTAKA}

Abu Huraerah. Kekerasan Terhadap Anak. Nuansa, Bandung, 2006

Bambang Sunggono, Hukum dan Kebijaksanaan Publik, Sinar Grafika, Jakarta, 2002

Marlina, Peradilan Pidana Anak Di Indonesia pengembangan konsep diversi dan keadilan restoratif, Refika Aditama, Bandung, 2009

R. Subekti dan Tjitrosoedibyo, Kamus Hukum, Pradnya Paramita,Jakarta,2005

Siti Zaenab, Perlindungan Hukum Terhadap Anak Sebagai Kurir Narkotika, Univ. Narotama, Surabaya: 2014 